\title{
Touch not the fish: the Mesolithic- Neolithic change of diet and its significance
}

Stable isotope analysis has startled the archaeological community by showing a rapid and widespread change from a marine to terrestrial diet (ie from fish to domesticated plants and animals) as people moved from a Mesolithic to a Neolithic culture. This could be a consequence of domestication, or as Julian Thomas (2003) proposed, of a kind of taboo ('Touch not the fish'). In a key challenge, Nicky Milner and her colleagues (2004) questioned the reality of this nutritional revolution, contrasting the message of the bones and shells found on settlement sites, with the isotope measurements in the bones of people. Here Mike Richards and Rick Schulting, champions of the diet-revolution, strongly reinforce the arguments. The change was real, it seems: so what does it mean? Milner and colleagues respond.

Keywords: Northern Europe, Mesolithic, stable isotopes, diet, taboo

\section{Against the grain? A response to Milner et al. (2004)}

\author{
M.P. Richards ${ }^{1} \&$ R.J. Schulting ${ }^{2}$
}

\section{Introduction}

A recent publication in this journal (Milner et al. 2004) called into question the increasing body of human stable isotopic data showing a rapid diet shift away from marine resources associated with the beginning of the Neolithic in parts of north-western Europe, particularly in Britain and Denmark. While we very much welcome informed and positive debate on this issue, we feel we must respond to this specific paper as it is problematic at a number of levels.

Stable carbon and nitrogen isotope analysis of human bone is beginning to challenge what we would argue is the current orthodoxy of a gradual dietary transition between the Mesolithic and Neolithic. Indeed, the stable isotope data support some elements of a

1 Department of Human Evolution, Max Planck Institute for Evolutionary Anthropology, Deutscher Platz 6, Leipzig, D-04105, Germany, and Department of Archaeology, University of Durham, South Road, Durhom, DH1 3LE, UK (Email: richards@eva.mpg.de)

2 School of Archaeology and Palaeoecology, The Queen's University of Belfast, Northern Ireland, BT7 INN, UK (Email: r.schulting@qub.ac.uk) 


\section{M.P. Richards \& R.J. Schulting}

previous orthodoxy, which saw the advent of the Neolithic as a 'revolution'. This is not to say that all elements are supported by the isotopic data; the question of the interactions between any incomers and indigenous people, for example, is still very much a live issue. And it is still far from clear exactly how the shift occurred, how rapid it was in human terms (in generations rather than radiocarbon years), and why it occurred. And there is still the possibility of regional and supra-regional variation to be addressed fully. But the implications of the stable isotope data are beginning to be acknowledged and addressed (e.g. Thomas 2003). This is an important independent line of evidence, and has been available since the early 1980s (Tauber 1981a), yet until recently little consideration has been given to the picture of a very rapid and significant shift in diet across the Mesolithic-Neolithic transition. Instead, it is during this very period that the view of the transition as a long, drawn-out process began to emerge and dominate discussion (Thomas 1991).

It is in this context that criticisms made of the isotopic data, particularly by Milner et al. (2004) need to be addressed. Their dismissal of the isotopic evidence for a rapid and significant transition, while to some extent encouraging debate, also prematurely attempts to close it. Milner et al. (2004) present their critique along three main fronts (see also Bailey \& Milner 2002). Firstly, they contend that the zooarchaeological and archaeological evidence for diet is at odds with the stable isotope data; secondly, they point to problems of sample size and bias in the human skeletons used for analysis; and thirdly, they argue that there are problems with the interpretation of stable isotope data. We address each of these concerns in turn.

\section{The (zoo)archaeological data}

Milner et al. (2004) make much of the zooarchaeological evidence for the continued use of marine resources in the Neolithic, taking examples mainly from Denmark but also from Britain and Ireland. They argue that the presence of the remains of marine foods (especially shellfish) in Neolithic contexts, and the occurrence of apparent seal-hunting stations and of fish traps, somehow counters any argument of a large-scale dietary shift at the start of the Neolithic. Despite the numerous problems and biases with the use of zooarchaeological data, they present this evidence as if it were some sort of 'spoiler'; that finding any evidence, however slight, of any Neolithic person consuming marine foods undermines the isotopic data of a large scale shift. Simply put, the continued occasional use of marine resources in the Neolithic is not at all incompatible with the isotope data, but is largely irrelevant in the overall question of large-scale dietary shifts. The isotopic evidence presents a long-term measure of lifetime diets, and clearly shows a significant change in human diet between the Mesolithic and the Neolithic. Remains of fish and shellfish recovered from archaeological sites are the remains of individual meals, but are not indicative of the overall diet of a human population. As Geoff Bailey himself has elegantly argued (Bailey 1975, 1978), shells are highly visible archaeologically due to their preservational properties, but misleading in terms of determining diet composition, as they are nutritionally poor. Bailey (1978) writes that:

'The ease with which molluscs can be over-rated as a source of food will be swiftly appreciated from the fact that approximately 700 oysters would be needed to supply enough kilocalories for one person for one day, if no other food were eaten, or 1400 cockles, 
or 400 limpets, to name the species most often found in European middens. I have estimated that approximately 52,267 oysters would be required to supply the calorific equivalent of a single red deer carcase, 156,800 cockles, or 31,360 limpets, figures which may help to place in proper nutritional perspective the vast numbers of shells recorded archaeologically.' ～(Bailey 1978: 39, emphasis ours)

Therefore, the occasional Neolithic shell midden is in itself hardly indicative of a continued marine-based economy in this period. The nature of the exploitation may have been very different, for example, from a central aspect of subsistence in the Mesolithic to one more peripheral in the Neolithic.

In addition, it should be emphasised that, aside from these shell middens and special purpose sites, there are actually very few Neolithic faunal assemblages known from Denmark. Bone survival is poor away from the shell middens, but where mammalian fauna is preserved from the Early Neolithic, it is dominated by domestic fauna (see Fischer 2002 for a recent review). Thus Milner et al.'s (2004) discussion touches upon only one aspect of the Neolithic economy, and likely a very limited one.

In the context of Britain, where much of our own research on this issue has been focused (i.e. Richards \& Hedges 1999; Richards et al. 2003a; Schulting \& Richards 2002a, b), Milner et al. (2004) do agree that there is substantially less evidence for marine exploitation in the Neolithic. They suggest that this is partly because of inundation of coastal sites by rising sea levels. However, sea levels were quite close to their present position by $4000 \mathrm{cal}$ BC (the generally accepted data for the appearance of Neolithic material culture in the UK), so that this argument holds far less relevance than it does for the Mesolithic period, when it is very much a factor (Schulting \& Richards 2002a, b). Milner et al. point to shell middens of Neolithic date along the Firth of Forth in south-east Scotland and along the coast of Co. Sligo, western Ireland, and to evidence for fishing from Neolithic Orkney. The shell middens are subject to the same issues already raised above- their simple presence, while certainly interesting and worthy of further investigation—says little about their quantitative importance in long-term diet. The Forth and Sligo middens are notable for the absence of much in the way of cultural material, or indeed fauna aside from oyster shell (Sloan 1982). Indeed, at least some of the Forth shell middens have been argued to represent largely natural accumulations (Jardine 1984), albeit with intermittent occupation indicated by hearths, possibly taking advantage of their good drainage properties. A number of fish bones have been found inside the chambers of some Orcadian Neolithic tombs, although it is not entirely clear that all of these represent human activity. Otters and other predators used the tombs as dens, and could have introduced some of this material. But it is likely that some fishing was indeed practiced at this time (Colley 1983; Wheeler 1983); nevertheless, once again, this gives no indication of its importance in the overall subsistence economy. The few available human stable isotope results from Orkney have typically terrestrial values, though these were obtained incidentally as part of the radiocarbon dating process, and need to be re-visited (this is the subject of ongoing research).

In the face of what Milner et al. (2004) regard as conflicts between the isotopic and archaeological lines of evidence, it is worth noting that the British Neolithic faunal evidence demonstrates an overwhelming reliance on domesticated species, particularly cattle 


\section{M.P. Richards \& R.J. Schulting}

(Armour-Chelu 1998; Grigson 1999; Legge 1981; Stallibrass \& Huntley 1996; Tresset 2000, 2003). The sites from which these assemblages derive are admittedly largely inland, but, just as we have argued that coastal resources ceased being exploited with any consistency and intensity, so too it appears that the hunting of wild game ceased to be an important economic activity in the Neolithic in parts of north-west Europe. The same dominance of domestic fauna also applies to the earliest Neolithic faunal assemblage from Orkney, that of Knap of Howar (Noddle 1983; Schulting et al. 2004). In this sense the British Neolithic isotopic data is not in the degree of conflict with the zooarchaeological data intimated by Milner et al. Therefore, both the British faunal and isotopic data indicate the rapid and widespread uptake of domesticates in the Neolithic, in both inland and coastal areas.

\section{Sample bias?}

Milner et al. (2004) rightly acknowledge that the (zoo)archaeological data and the isotopic data are referring to different scales of analysis. There may be some question, however, as to the extent to which the former necessarily refer to 'generalised dietary tendencies over long periods' as they claim (Milner et al. 2004: 12). Some faunal assemblages may reflect relatively short-term or special purpose use, and may have little to do with overall, long-term diet. Again, there is a tendency to overlook possible biases in their own data. This tendency is repeated in their conclusions, where they again imply that 'traditional sources of palaeodietary information give us a generalised picture of subsistence within the catchment of an archaeological deposit' (Milner et al. 2004: 19). This presents a rather problematic view of archaeological formation processes, in which all subsistence resources used by a group of people within an area will somehow conveniently end up, represented in correct proportions, on a site for us to find. Leaving this aside, in both instances the main point they want to make is that the isotopic data is very limited in scope, referring as it does to the long-term diets of specific individuals.

The contention that only a very small sample of the total population of the Mesolithic and Neolithic from the countries in question has been analysed is certainly true. We have, for example, endeavoured to measure the isotopic values of every human dated to the Mesolithic in Britain; in fact we have specifically sought out contexts with human remains likely to date to the Mesolithic (Schulting \& Richards 2002b), yet the number of these remains small. For the British Neolithic, there is a much larger database, with hundreds of individuals measured and with approximately 200 of these directly radiocarbon dated. None of these, from whatever context and from both inland and coastal regions, have isotopic signals indicative of any significant consumption of marine foods. By 'significant' we mean more than 5-15 per cent consumption of marine protein, which is near the resolution limits of the technique for an individual. Nevertheless, it is also worth pointing out that grouped comparisons of individuals from near-coastal (within $10 \mathrm{~km}$ of the sea) also do not reveal any differences $\left(\delta^{13} \mathrm{C}=-20.8 \pm 0.7 \%\right.$ or 68 humans from 19 coastal sites, compared to $-20.7 \pm 0.7 \%$ or 99 humans from 25 inland sites) (Richards et al. 2003a). The interpretation placed on this by Milner et al. (2004), that the results are therefore potentially idiosyncratic and unrepresentative, shows a misunderstanding of probability. If such a small subset of a population is being sampled, the chance of repeatedly picking out rare 
cases with unrepresentative diets becomes even more remote. Thus, if anything, this actually supports the argument that the individuals measured $d o$ accurately reflect the norm at this time, at least for those areas and time periods that are represented. The Neolithic sample in particular (and this is key to their argument) is hardly unrepresentative and it would be extremely unlikely that we had repeatedly sampled unusual or idiosyncratic individuals.

Indeed, one could very easily apply the comments made by Milner et al. (2004) on sample size problems to their own zooarchaeological data. The amount of food actually represented in all the known faunal assemblages from the Neolithic of both Denmark and Britain must represent only a very tiny fraction of all the foods consumed by the hundreds of thousands of individuals who lived over a period of some 1000 years. Again, this bias is not recognised. Nor, following on from the above discussion, do we wish to pursue it here other than to point out that this kind of problem affects most prehistoric archaeology, no matter what kinds of remains are being discussed.

That those individuals sampled from Britain derive predominantly from monumental mortuary contexts and causewayed enclosures does present another possibility, that of an elite with privileged access to the new, high-status domesticated foods. We have addressed this issue elsewhere, and find it unlikely on a number of grounds (Schulting \& Richards 2002a, b; Schulting 2004). A number of coastal British samples derive from caves rather than monumental contexts, and these show no systematic difference in their isotopic values either for carbon or nitrogen. Similarly, a number of Danish Neolithic samples derive from flat graves and chance bog finds; indeed, for the early part of the Neolithic, these outnumber samples from monumental mortuary contexts.

The proposition that the observed differences could be related to age or sex differences (Milner et al. 2004: 15), while certainly worth considering, also fails to convince as an explanation in this instance. Males and females, adults and subadults, are all represented in the Neolithic dataset. Sample size becomes increasingly problematic as the total sample is subdivided by age and sex, and it remains possible that a finer-grained analysis would reveal some dietary distinctions. However, these would very likely be quite subtle ( $c f$. Schulting $\&$ Richards 2001), and cannot be used to account for the massive isotopic differences seen between most coastal Mesolithic individuals, and all coastal Neolithic individuals (in Denmark, Britain, and also Brittany) analysed to date.

\section{Neolithic variability?}

The fact that Mesolithic diets were variable, as alluded to by Milner et al. (2004; and also noted in Schulting \& Richards 2002a), with isotopic results indicating the coexistence of both marine and terrestrial dominated diets, does not affect our argument. Our main contention is that Neolithic diets, at least in those areas sampled to date, are far less variable and are predominantly terrestrial.

Curiously, Milner et al. (2004: Figures 1a, b) actually present much of our stable isotope data in their paper, and then use these in support of their arguments for a gradual dietary transition, although, in our opinion, their graphs actually support the idea of the dramatic change that we have highlighted. It is unclear to us how Milner et al. can strongly criticise a method and then utilise it, in the very same paper, to support their own arguments. Surely, 
they cannot have it both ways? But, to take the case as Milner et al. (2004: 13) present it, Figures $1 \mathrm{a}$ and $1 \mathrm{~b}$ are used to point to a small number of cases of 'considerable overlap' near the crucial period of $4000 \mathrm{cal}$ BC. The first impression of their Figure 1a is one of an abrupt and overwhelming disjunction at $4000 \mathrm{BC}$. The chronological 'overlap' alluded to consists entirely of the tail ends of 2 sigma error bars. Nor does this graph take any account of the context of the samples. The latest and highly marine influenced Mesolithic samples derive from the Oronsay shell middens on the west coast of Scotland (Richards \& Mellars 1998; Richards \& Sheridan 2000). There is no indication of any Neolithic presence whatsoever at these sites. This, together with their relatively isolated geographical position, strongly suggests that these were among the last individuals on the west coast of Scotland to follow a purely, perhaps even exaggerated, 'Mesolithic' way of life ( $c f$. Mithen 2000).

For Denmark also, the strongest impression by far is unquestionably that of a sharp dietary shift at c. 4000 BC (Milner et al. 2004: Figure 1b). In some ways paralleling Oronsay, there are a small number of very late individuals that show very high marine isotopic signatures, and are responsible for an 'overlap'. The most important of these is Dragsholm (Tauber 1981a, b; 1983), previously highlighted as a crucial site in understanding how complete and rapid the Mesolithic-Neolithic transition may have been in terms of a dietary shift (e.g. Richards et al. 2003b; Schulting 1998). Here, a double burial of two adult females was found within only two metres of an adult male grave. The females showed extremely elevated $\delta^{13} \mathrm{C}$ values of $-11.5 \%$ and $-12.2 \%$, indicating that essentially all of their protein came from the sea, while the male shows a strongly terrestrial result of $-21.7 \%$ (Tauber 1981b). Although the originally available radiocarbon dates certainly allow the possibility of contemporaneity (Milner et al. 2004, Figure 2), the material culture in the graves was purely Mesolithic in the case of the female grave, and purely Neolithic in the case of the male grave. This, together with the complete dietary separation, would be a remarkable situation if the two graves were indeed contemporary and belonged to the same culture. Fischer's (2002) suggestion cited by Milner et al., that they represent a man and his wives, is simply incorrect. New dating and stable isotope analyses on the two graves demonstrate both their dietary and chronological separation (Price et al. in press).

\section{Stable isotopes and human diet}

The final aspect of Milner et al.'s (2004) critique relates to the stable isotope method itself, and to the interpretation of the results. Before responding in detail, it is worth emphasising that this method of reconstructing diets of humans and fauna has been applied in archaeology, ecology, and zoology for at least twenty-five years, and that the basic models for the differences in isotopic signatures are based on hundreds of studies, both modern and archaeological. There are a number of excellent reviews, as well as readily accessible metaanalyses which group together the many thousands of published results and which firmly support the robustness of this method, especially in identifying marine $v$ s. terrestrial diets (Peterson \& Fry 1987; Owens 1987; Kelly 2000; Vanderklift \& Ponsard 2003; Post 2002). Thus is it difficult to sustain Milner et al.'s (2004: 19) criticism that we have exaggerated the power of the technique. This is not to say that questions and issues do not remain, but the 
basic workings of the technique are quite well understood, and have been tried and tested repeatedly.

Milner $e$ al. question a number of aspects of the interpretation of stable isotope data. One point made is that marine $\delta^{13} \mathrm{C}$ signals can enter the human food web indirectly, through practices such as foddering and manuring. This is only partly true. Foddering, for example with seaweed, can introduce elevated $\delta^{13} \mathrm{C}$ values, such as seen in some modern sheep in parts of Orkney (Ambers 1990). And, most intriguingly, there is new evidence of this practice from Neolithic Orkney (Balasse et al. 2005). The effect of this on human consumers is currently being investigated, as it is likely to have made an impact on $\delta^{13} \mathrm{C}$ values, though less so on $\delta^{15} \mathrm{~N}$ values. But their suggestion that manuring could equally affect $\delta^{13} \mathrm{C}$ values is simply mistaken. Terrestrial plants derive their carbon from the atmosphere, not from the soil (nitrogen, on the other hand, could be affected, depending on the plant species and the depth of the soil). In either case, the whole point of the available $\delta^{13} \mathrm{C}$ values for the Neolithic is that there is minimal evidence for marine input, so the relevance of this as a critique is unclear (and indeed, it is only used as a lead-in to their next point, discussed below).

The issue of isotope ecology next raised by Milner et al. (2004) is an important one. Specifically, they argue that estuarine systems can show depleted $\delta^{13} \mathrm{C}$ values, as there is a high input from terrestrial, freshwater systems. We concur that it has been observed in some estuaries that aquatic fauna have less depleted $\delta^{13} \mathrm{C}$ values (e.g. Peterson et al. 1985). Indeed, this was intimated in a stable isotope study of Mesolithic and Neolithic humans in Portugal, where Mesolithic humans clearly had a recognisably distinct $\delta^{13} \mathrm{C}$ value of c. $-15 \%$ o, compared with the Neolithic terrestrial value of $-20 \%$ (Lubell et al. 1994; see also Jonsson 1988 on Skateholm in southern Scania, Sweden). A similar situation applies to much of the Baltic, and especially the eastern Baltic, which oscillated throughout its history between freshwater, brackish and marine (Christensen 1995; Berglund et al. 2005). Even seals here at certain periods can have a very 'terrestrial' looking $\delta^{13} \mathrm{C}$ signature (Lidén et al. 2004; Lougas et al. 1996). This is hardly the 'open sea' that Milner et al. refer to as being isotopically variable, nor is the long Limfjord of northern Jutland.

But the special conditions indicated above are not, we would argue, nearly sufficient to support the weight of interpretation that Milner et al. (2004) place on it. The main point about estuaries is that they are complex and highly variable habitats, and this is reflected in their isotope ecology. Only sessile organisms such as shellfish, living in the estuary all of their lives, would show the full effect of the brackish water conditions, with possibly high freshwater input (and hence, depleted $\delta^{13} \mathrm{C}$ values). Milner et al. note this but do not fully explore its implications. Many other organisms make use of estuaries for only part of the year, and these organisms would be far less affected by the local $\delta^{13} \mathrm{C}$ conditions. And it is just such organisms that, in many cases, should be most attractive to human consumers if marine resources were being seriously exploited. The best example would be various fish species congregating for spawning, or in preparation for further movement upriver, such as in the case of salmon. Such species show a predominantly marine $\delta^{13} \mathrm{C}$ signal, since they spend most of their lives feeding in the sea. For estuaries to so drastically affect the isotopic signature of human consumers implies that only local shellfish and fish species were being exploited, leaving, presumably, the bulk of the diet to come from somewhere else. But, do Milner et al. seriously suggest that the reason that every coastal Neolithic human in Britain 
that has been measured has a terrestrial $\delta^{13} \mathrm{C}$ value is because there was a shift to using only estuarine, not open marine, resources (and only some estuarine species at that)? And also, that this happened to coincide with an exceptional phenomenon whereby all of the estuarine resources in Britain happened to have, at that time, terrestrial-like $\delta^{13} \mathrm{C}$ values, a phenomenon that was not in effect in the Mesolithic or subsequent periods? The evidence from the Neolithic of Britain and Denmark is simply too widespread and too consistent to support such a contention. There are measurements on more than 70 individuals from over 20 sites within $10 \mathrm{~km}$ of the British coast, and none show any significant input of marine foods (Richards et al. 2003a; Schulting 2004). Nor do the great majority of these coastal values derive from the vicinity of a large estuary. Thus this cannot be used to explain the observed human terrestrial isotopic signatures. A far more parsimonious explanation is that, as we have argued, the appearance of farming resulted in a strong and rapid shift to an economic emphasis on domesticated resources.

While we agree that additional estuarine and freshwater faunal remains of the appropriate age would be useful in fine-tuning the interpretation of stable isotope measurements on humans, the reality is that little or no such material exists, at least for much of Britain outside of Orkney. However, this is not to say, as Milner et al. (2004) seem to imply, that no such comparative values are available. Where $\delta^{13} \mathrm{C}$ values have been obtained on bone collagen (from Mesolithic and Neolithic contexts in Scotland, Wales, Denmark and Brittany, as well as more recent periods), they are on the order of $-11 \%$ to $-14 \%$, as expected for open sea marine ecosystems (Richards \& Mellars 1998; Schulting \& Richards 2002a, b; unpublished data).

The next aspect of Milner et al.'s (2004) critique relates to considerations of how the carbon and nitrogen from food items enter into bone collagen. Many of the points raised are dealt with by Hedges (2004) in his response to their paper, so there is no need to reconsider those issues in great detail here. But the issue is important enough to warrant some additional clarification.

As summarised by Milner et al., Ambrose and Norr's (1993) feeding experiments on rats showed that, when adequate protein is consumed, dietary proteins are routed directly into bone collagen. This is the model most often employed in stable isotope studies, where it is recognised that measurements predominantly reflect sources of dietary protein rather than carbohydrates or lipids. However, the same feeding experiments indicate that, when low-protein ( $c .5$ per cent) diets are consumed, there is a more general contribution from total dietary protein, and so a greater contribution from the carbon in carbohydrates and lipids. None of this is in question, though the conclusions that Milner et al. (2004) draw from this are.

Hedges (2004), in responding to a number of the criticisms of the isotopic technique made by Milner et al. (2004) presents a scenario in which bone collagen $\delta^{13} \mathrm{C}$ values for humans with up to 20 per cent of their total protein intake being from marine sources, could still have terrestrial-like $\delta^{13} \mathrm{C}$ values if the rest of their diet was dominated by carbohydrates and lipids from plant foods. For this to occur, the humans would need to be living on a very low protein diet (e.g. less that 5 per cent of their caloric intake if we use the Ambrose and Norr model - Hedges does not actually define this in his paper), and then consume a large quantity of low protein plant foods. Most plant foods are indeed low in protein, but 
processed cereals, such as porridges and breads, do have significant amounts (e.g. 9 grams per 100 grams of edible portion for whole wheat bread, compared to 23 grams per 100 for raw deer) of accessible protein (USDA 2004). Putting aside the difficulties of verifying a purely theoretical and mathematical model as presented by Hedges, this sort of result would require a very special type of diet indeed, one consisting entirely of cereals and shellfish. Shellfish, rather than other marine species, become necessary in this scenario, as Milner et al. note, because $\delta^{15} \mathrm{~N}$ measurements are not affected by routing issues, since nitrogen is only found in protein, and so cannot derive from other components of the diet. $\delta^{15} \mathrm{~N}$ values support a strong distinction between the Mesolithic and Neolithic (with more elevated values seen in the Mesolithic). To explain the $\delta^{15} \mathrm{~N}$ values following their argument, only low trophic level marine foods, such as shellfish, could contribute any significant element of the diet and still preserve the observed difference in $\delta^{15} \mathrm{~N}$ values.

It is almost unnecessary to point out that such a diet is unlikely to describe the Neolithic of Denmark and Britain. As noted earlier, and in the case of Britain in particular, we have abundant evidence for the consumption of domestic fauna, particularly cattle. Thus it is hard to sustain the kind of cereal-based, low-protein diet that is a precondition in masking a contribution of up to 20 per cent marine protein to the total dietary protein.

Finally, even accepting the possibility of this very odd diet, the sudden switch to an economy so dominated by domesticated cereals would constitute, in our opinion, a far more striking and surprising shift than the one we have postulated, despite the continued use of marine resources (still a relatively minor component of the diet) that it allows. It is surely special pleading, and again unsupported by any actual data, to argue for a specific diet that would mask the intake of marine foods in the isotope values due to the consumption of large amounts of domesticated plant foods. This is strange reasoning to support their view of a gradual dietary transition, as any suggested move from a marine based diet to one with mostly domesticated plant foods is a significant change of diet in the Neolithic.

\section{Ethnographic analogies}

Milner et al. state that it is 'theoretically implausible' that people in the Neolithic would turn their backs on the 'cornucopia' provided by the sea (Milner et al. 2004: 18-9). This is a curious assertion, as there are numerous well-known cases of groups of people avoiding certain classes of foods, including both freshwater and marine foods (Malainey et al. 2001; Simoons 1994). Indeed, there are decades of anthropological research and debate on this very topic, with the debate concerned with reasons behind such avoidances, not the fact of the avoidances themselves (Douglas 1984; Harris 1986, 1987). In their closing sections, Milner et al. (2004) seem to implicitly invoke an argument for a rather naive economic rationality: seafood is there, it should be used. This position is particularly ironic given that Britain is so well known today for exporting most of the fish in its coastal waters to other European countries. Surprisingly, in an argument for economic 'rationality', Milner et al. take no account of decades of research on optimal foraging theory (Hawkes \& O'Connell 1992; Winterhalder 1993). They take no account of variability in coastal access, and in the limitations of technology. Straight coastlines, for example, offer no easy access to deeper water. The fact that people were travelling on the sea, as indicated by trade in materials, 


\section{M.P. Richards \& R.J. Schulting}

is quite a different thing than extracting resources from the sea. Time taken in collecting shellfish or in fishing is time lost from other activities that may yield higher returns. Regardless of how 'rich' the sea is, if an even more efficient and productive alternative is available, foraging theory predicts that it is the latter that will be emphasised. We are not necessarily making this case here, but offer this as one possible response to Milner et al.'s call for economic rationality.

\section{Conclusions}

To conclude, the isotopic evidence shows a rapid and clear change in diet associated with the earliest Neolithic in both Britain and Denmark. These results clearly go against the grain of much current archaeological thought on the nature of the Mesolithic and Neolithic transition, and especially against the view of the transition expounded by Milner et al. (2004).

Whether the avoidance (or certainly much reduced use) of marine foods seen in the Neolithic of Denmark and Britain is for 'practical' economic reasons, or for cultural reasons, is an interesting question and one that is being currently investigated and debated (Richards 2003; Schulting 2004; Thomas 2003). We do not see the explanation as likely to be a simple one. What we do argue on the basis of the stable isotope data obtained thus far, is that a real phenomenon can be observed, indicating a significant and rapid change in diet associated with the introduction of Neolithic material culture into Britain and Denmark around 4000 cal BC.

Milner et al. (2004: 10, 16, 18) misrepresent our position as stating that no Neolithic individuals ever ate any marine foods. The isotopic technique is not sensitive enough to permit any such claim, nor have we made it. What we have argued is that there seems, with very few exceptions, to be no detectable marine input in Neolithic individuals we have measured to date, and on this basis we argue that there appears to have been no significant dietary use of marine resources in the areas we have studied. And we recognise that there are some exceptions: 'Interestingly, a few value of around - 19.5\% could indicate some minimal input of marine protein (on the order of 5-10\% of the protein component) in the diet of some [Neolithic] individuals...' (Schulting \& Richards 2002a: 1023). The point is that this is of a completely different order to what is seen in the Mesolithic, and even then it is relatively rare on the basis of the available data (Schulting \& Richards 2002a, b). Nor has this fact been downplayed in an attempt to 'attract the attention of the archaeological community' (Milner et al. 2004: 19), although we do admit to making an effort to communicate what we see as a very interesting, robust and initially unexpected pattern. Again, this is not to say that regional variation may not be found, and additional analyses are currently underway to address just this issue (though preliminary results from North Wales, Orkney and the Channel Islands continue to support a strong dominance of terrestrial resources).

As Milner et al. note (2004: 19), zooarchaeological data and isotopic date operate at very different scales of analysis; they even suggest that using one technique as a cross-check on the other may be misleading (although this formed a major component of their critique). But this is the essence of interdisciplinary research, and we do not accept that the different scales of analysis are irreconcilable, although they are certainly challenging. Where new methods 
of analysis provide unexpected results, sometimes partly contradicting traditionally accepted views (and the 'slow transition model' is very much the new orthodoxy), there is clearly an opportunity to learn, and to expand our knowledge. Simple outright denial of the validity of one of the methods of analysis does not achieve this aim. Despite Higgs' cold water and Milner et al.'s undisguised pessimism, we feel that inter- and cross-disciplinary research offers great potential. In this spirit we might suggest that Milner et al. apply the principle of Occam's razor, which argues for the simplest, most parsimonious, interpretation of a dataset.

It is rare to get such clear differences between time periods in archaeology using any methodology, and we must engage with the isotopic data, as it is providing key clues to our understanding the nature of this enigmatic transition. We need to continue this isotopic work, comparing it with other lines of evidence, to get closer to understanding what happened at this key moment in the prehistory of these regions. Informed debate on this, and other, evidence is vitally important to better refine our methods of analysis.

\section{References}

Ambers, J.C. 1990. Identification of the use of marine plant material as animal fodder by stable isotope ratios. PACT 29: 251-8.

Ambrose, S.H. \& L. Norr. 1993. Experimental evidence for the relationship of the carbon isotope ratios of whole diet and dietary protein to those of bone collagen and carbonate, in J. Lambert \& G. Grupe (ed.) Prehistoric Human Bone: Archaeology at the Molecular Level: 1-37. New York: Springer-Verlag.

Armour-Chelu, M. 1998. The animal bone, in F. Pryor (ed.) Etton: Excavations at a Neolithic Causewayed Enclosure near Maxey, Cambridgeshire, 1982-7: 273-88. London: English Heritage.

Bailey, G.N. 1975. The role of molluscs in coastal economies: the results of midden analysis in Australia. Journal of Archaeological Science 2: 45-62.

-1978 . Shell middens as indicators of postglacial economies: a territorial perspective, in P. Mellars (ed.) The Early Postglacial Settlement of Northern Europe: An Ecological Perspective: 37-63. Pittsburgh (PA): University of Pittsburgh Press.

Bailey, G.N. \& N.J. Milner. 2002. Coastal hunter-gatherers and social evolution: marginal or central? Before Farming, the Archaeology and Anthropology of Hunter-Gatherers 3-4: 1-15.

Balasse, M., A. Tresset, K. Dobney \& S.H. Ambrose. 2005. The use of isotope ratios to test for seaweed eating in sheep. Journal of the Zoological Society of London 266: 283-91.

Berglund, B.E., P. Sandgren, L. Barnekow, G. Hannon, H. Jiang, G. Skog \& S.-Y. Yu. 2005. Early Holocene history of the Baltic Sea, as reflected in coastal sediments in Blekinge, southeastern Sweden. Quaternary International 130: 111-40.
Christensen, C. 1995. The Littorina transgressions in Denmark, in A. Fischer (ed.) Man and Sea in the Mesolithic: 15-22. Oxford: Oxbow.

Colley, S. 1983. Interpreting prehistoric fishing strategies: an Orkney case study, in C. Grigson \& J. Clutton-Brock (ed.) Animals and Archaeology: 2. Shell Middens, Fishes and Birds: 157-71. BAR International Series 183. Oxford: Archaeopress.

Douglas, M. 1984. Fundamental issues in food problems. Current Anthropology 25: 498-9.

FIscher, A. 2002. Food for feasting? An evaluation of explanations of the neolithisation of Denmark and southern Sweden, in A. Fischer \& K. Kristiansen (ed.) The Neolithisation of Denmark -150 Years of Debate: 343-93. Sheffield Archaeological Monographs 12. Sheffield: JR Collis Publications.

Grigson, C. 1999. The mammalian remains, in A. Whittle, J. Pollard \& C. Grigson (ed.) The Harmony of Symbols: The Windmill Hill Causewayed Enclosure, Wiltshire: 164-252. Oxford: Oxbow.

Harris, M. 1986. Good to Eat: Riddles of Food and Culture. New York: Simon and Schuster.

-1987. Foodways: Historical Overview and Theoretical Prolegomenon, in M. Harris \& Ross, E.B. (ed.) Food and Evolution: Toward a Theory of Human Food Habits: 57-90. Philadelphia (PA): Temple University Press.

Hawkes, K. \& J.F. O’Connell. 1992. On Optimal Foraging Models and Subsistence Transitions. Current Anthropology 33: 63-6.

Hedges, R.E.M. 2004. Isotopes and red herrings: comments on Milner et al. and Lidén et al. Antiquity 78: 34-7.

JARDINE, W.G. 1984. The role of geomorphology and geology in archaeological studies: a synopsis. Glasgow Journal of Archaeology 11: 1-11. 


\section{M.P. Richards \& R.J. Schulting}

Jonsson, L. 1988. The vertebrate faunal remains from the Late Atlantic settlement Skateholm in Scania, south Sweden, in L. Larsson (ed.) The Skateholm Project. I. Man and Environment: 56-88. Almqvist and Wiksell International, Stockholm: Acta Regiae Societatis Humaniorum Litterarum Ludensis LXXIX.

KelLy, J.F. 2000. Stable isotopes of carbon and nitrogen in the study of avian and mammalian trophic ecology. Canadian Journal of Zoology 78: 1-27.

Legge, A.J. 1981. Aspects of cattle husbandry, in R. Mercer (ed.) Farming Practice in British Prehistory: 169-81. Edinburgh: Edinburgh University Press.

Lidén, K., G. Eriksson, B. Nordqvist, A. Götherström \& E. Bendixen. 2004. “The west and the wild followed by the dry and the tame" - or did they occur at the same time? Diet in Mesolithic-Neolithic southern Sweden. Antiquity 78: 23-33.

Lubell, D., M. Jackes, H. Schwarcz, M. Knyf \& C. Meiklejohn. 1994. The Mesolithic-Neolithic transition in Portugal: Isotopic and dental evidence of diet. Journal of Archaeological Science 21: 201-16.

Lôugas, L., K. Lidén \& D.E. Nelson. 1996. Resource utilization along the Estonian coast during the Stone Age. PACT 51: 399-420.

Malainey, M.E., R. Przybylski \& B.L. Sherriff. 2001. One Person's Food: How and Why Fish Avoidance May Affect the Settlement and Subsistence Patterns of Hunter-Gatherers. American Antiquity 66: 141-61.

Milner, N., O.E. Craig, G.N. Bailey, K. Pedersen \& S.H. Andersen. 2004. Something fishy in the Neolithic? A re-evaluation of stable isotope analysis of Mesolithic and Neolithic coastal populations. Antiquity 78: 9-22.

Mithen, S. 2000. Mesolithic sedentism on Oronsay: chronological evidence from adjacent islands in the Southern Hebrides. Antiquity 74: 298-304.

Noddle, B. 1983. Mammal remains from Knap of Howar, Orkney, in A. Ritchie (ed.) Excavation of a Neolithic farmstead at Knap of Howar, Papa Westray, Orkney. Proceedings of the Society of Antiquaries of Scotland 113: 92-100.

Owens, N. 1987. Natural variations in ${ }^{15} \mathrm{~N}$ in the marine environment. Advances in Marine Biology 24: 389-451.

Peterson, B.J., R.W. Howarth \& R.H. Garritt. 1985. Multiple stable isotopes used to trace the flow of organic matter in estuarine food webs. Science 227: $1361-3$

Peterson, B.J. \& B. Fry. 1987. Stable isotopes in ecosystem studies. Annual Reviews of Ecological Systems 18: 293-320.
Post, D.M. 2002. Using stable isotope models to estimate trophic position: Models, methods and assumptions. Ecology 83: 703-18.

Price, T.D., P. Bennike, E. Brinch Petersen, N. Noe-Nygaard, S. Ambrose, M.P. Richards, P. Vang Petersen \& J. Heinemeier. in press. The stone age graves at Dragsholm, Denmark: New dates, isotopes and other information. Acta Archaeologica.

Richards, M.P. 2003. Explaining the dietary isotope evidence for the rapid adoption of the Neolithic in Britain, in M. Parker-Pearson (ed.) Food, Culture and Identity in the Neolithic and Early Bronze Age: 31-6. BAR International Series 1117. Oxford: Archaeopress.

Richards, M.P. \& R.E.M. Hedges. 1999. A Neolithic revolution? New evidence of diet in the British Neolithic. Antiquity 73: 891-7.

Richards, M.P., R.J. Schulting \& R.E.M. Hedges. 2003a. Sharp shift in diet at onset of Neolithic. Nature 425: 366.

Richards, M.P., T.D. Price \& E. Кoch. 2003b. The Mesolithic/Neolithic Transition in Denmark: New stable isotope data. Current Anthropology 44: 288-94.

Richards, M.P. \& P. Mellars. 1998. Stable isotopes and the seasonality of the Oronsay middens. Antiquity 72: 178-84.

Richards, M.P. \& J.A. Sheridan. 2000. New AMS dates on human bone from Mesolithic Oronsay. Antiquity 74: 313-5.

Schulting, R.J. 1998. Slighting the sea: the transition to farming in northwest Europe. Documenta Praehistorica 25: 203-18.

-2004. An Irish Sea change: some implications for the Mesolithic-Neolithic transition, in V. Cummings \& C. Fowler (ed.) The Neolithic of the Irish Sea: Materiality and Traditions of Practice: 22-8. Oxford: Oxbow.

Schulting, R.J. \& M.P. Richards. 2001. Dating women and becoming farmers: new palaeodietary and AMS data from the Breton Mesolithic cemeteries of Téviec and Hoëdic. Journal of Anthropological Archaeology 20: 314-44.

-2002a. Finding the coastal Mesolithic in southwest Britain: AMS dates and stable isotope results on human remains from Caldey Island, Pembrokeshire, South Wales. Antiquity 76: 1011-25.

$-2002 \mathrm{~b}$. The wet, the wild and the domesticated: the Mesolithic-Neolithic transition on the west coast of Scotland. European Journal of Archaeology 5: 147-89. 


\title{
Response to Richards \& Schulting
}

Schulting, R.J., A. Tresset \& C. Dupont. 2004. From harvesting the sea to stock rearing along the Atlantic façade of north-west Europe. Environmental Archaeology 9: 143-54.

Simoons, F.J. 1994. Eat Not This Flesh: Food Avoidances from Prehistory to the Present. Madison (WI): University of Wisconsin Press.

SLOAN, D. 1982. Nether Kinneil. Current Archaeology 84: $13-5$.

Stallibrass, S. \& J.P. Huntley. 1996. Slim evidence: a review of the faunal and botanical data from the Neolithic of northern England, in P. Frodsham (ed.) Neolithic Studies in No-Man's Land: 35-42. Northern Archaeology Volume 13/14, Journal of the Northumberland Archaeological Group.

TAuber, H. 1981a. 13C evidence for dietary habits of prehistoric man in Denmark. Nature 292: 332-3.

-1981 b. Kostvaner i forhistorisk tid - belyst ved C-13 målinger. In Det skabende menneske, pp. 112-26. Copenhagen: National Museum.

$-1983 .{ }^{14} \mathrm{C}$ dating of human beings in relation to dietary habits. PACT 8: 365-75.

Thomas, J. 1991. Rethinking the Neolithic. Cambridge: Cambridge University Press.

-2003. Thoughts on the 'repacked' Neolithic revolution. Antiquity 77: 67-74.
Tresset, A. 2000. Early husbandry in Atlantic areas. Animal introductions, diffusions of techniques and native acculturation at the north-western fringe of Europe, in J.C. Henderson (ed.) The Prehistory and Early History of Atlantic Europe: 17-32. BAR International Series 861. Oxford: Archaeopress.

-2003. French connections II: of cows and men, in I. Armit, E. Murphy, E. Nelis \& D. Simpson (ed.) Neolithic Settlement in Ireland and Western Britain: 18-30. Oxford: Oxbow.

U.S. Department of Agriculture, Agricultural Research Service. 2004. USDA Nutrient Database for Standard Reference, Release 17. Nutrient Data Laboratory Home Page, http://www.nal.usda.gov/ fnic/foodcomp

VanderKlift, M.A. \& S. Ponsard. 2003. Sources of variation in consumer-diet $\delta^{15} \mathrm{~N}$ enrichment: a meta-analysis. Oecologia 136: 169-82.

Wheeler, A. 1983. Fish remains from Knap of Howar, Orkney, in A. Ritchie (ed.) Excavation of a Neolithic farmstead at Knap of Howar, Papa Westray, Orkney. Proceedings of the Society of Antiquaries of Scotland 113: 103-5.

Winterhalder, B. 1993. Work, Resources and Population in Foraging Societies. Man 28: 321-40.

\section{A response to Richards and Schulting}

\author{
N. Milner ${ }^{1}$, O.E. Craig ${ }^{2}$, G.N. Bailey ${ }^{1} \&$ S.H. Andersen ${ }^{3}$
}

We welcome the comments of Mike Richards and Rick Schulting; however, rather than attempting to close the debate on the isotope evidence and the Mesolithic-Neolithic transition, as suggested in their introduction, we agree that the issues raised should be widely discussed and subject to critical and well informed scrutiny. We certainly did not attempt a 'simple outright denial of the validity of one of the methods of analysis' (i.e. stable isotopes); rather we wished to make the point that interpretations have to take into account uncertainties associated with the measurements. We have been pleased by the discussion that our article has invoked: two published responses (Barbarena \& Borrero 2005; Hedges 2004) and numerous personal communications which have been supportive and critical in

Department of Archaeology, University of York, King's Manor, York, YO1 7EP, UK

2 Centro di antropologia molecolare per lo studio del DNA antico, Dipartimento di Biologia, Università di Roma "Tor Vergata", Via della Ricerca Scientifica 1, 00133 Roma, Italy

3 Senior researcher, The National Museum of Denmark, Frederiksholms Kanal 12, DK-1220 København K, Denmark 